\title{
GENDER, POLITIK DAN AGAMA
}

\author{
Dendi Sutarto \\ Ilmu Pemerintahan Fakultas Ilmu Sosial dan Ilmu Politik \\ Universitas Riau Kepulauan \\ dendi_sutarto@yahoo.co.id
}

\begin{abstract}
Muhammadiyah is the largest religious social movement in Indonesia, based in Yogyakarta, Yogyakarta. The organization was founded on 8 Dhu al-Hijjah $1330 \mathrm{H}$ or November 18, 1912 in Yogyakarta by KHAhmad Dahlan, the movement known as the Islamic purification movement " amal ma'ruf nahi munkar ", but what counts Muhammadiyah became the basis of religion in the construction and reproduction root doctrine on value socio-cultural-value in the relationship between men and women as well as a political legitimacy on gender inequality in Muhammadiyah. This research is a field research, using methods kualitatfi with the sociological approach-fenomenolis reinforced by some theoretical analysis of Antonio Gramsci with terminology hegemony, Michel Foucult, with power relations the history of sexuality and assisted by other theories one structural functionalism. From the findings of this study that gender inequality and the strong role of religion as a value in the process of construction and reproduction of gender in the Muhammadiyah movement.
\end{abstract}

Keywords: religion, gender, politics, construction, muhammadiyah

\begin{abstract}
Abstrak
Muhammadiyah merupakan gerakan sosial keagamaan yang terbesar di Indonesia, yang berpusat di Yogyakarta, Daerah Istimewa Yogyakarta. Organisasi ini didirikan pada 8 Dzulhijjah $1330 \mathrm{H}$ atau 18 Nopember 1912 M di Yogyakarta oleh K.H.Ahmad Dahlan, gerakan ini dikenal sebagai gerakan purifikasi Islam "amal ma'ruf nahi munkar", namun problemnya basis agama di Muhammadiyah menjadi akar kontruksi dan reproduksi doktrin atas nilai-nilai sosio cultural dalam relasi laki-laki dan perempuan sekaligus menjadi legitimasi politik atas ketidakadilan gender di Muhammadiyah. Penelitian ini adalah penelitian lapangan, menggunakan metode kualitatfi dengan pendekatan sosiologis-fenomenolis yang diperkuat oleh beberapa analisis teoritis dari Antonio Gramsci dengan terminology hegomoni, Michel Foucult, dengan relasi kuasa the history of sexuality dan dibantu oleh teori lainnya salah satunya fungsionalisme struktural. Dari hasil temuan penelitian ini bahwa ketimpangan gender dan kuatnya peran agama sebagai nilai dalam proses konstruksi dan reproduksi gender di gerakan Muhammadiyah.
\end{abstract}

Kata kunci: agama, gender, politik, konstruksi, muhammadiyah

\section{A. Latar Belakang Masalah}

Kajian terhadap hubungan perempuan dan laki-laki dalam "struktur" organisasi Muhmmadiyah sebagai sebuah institusi sosial-keagamaan yang cukup kompleks terutama adanya pemisahan struktur secara institusionalisasi yang 
terbagi ke dalam dua variates yaitu Muhammadiyah disatu sisi yang lebih didominasi oleh kaum laki-laki (kaum adam) sedangkan di pihak lain ada institusi Aisyiyah yang secara khusus berbasis para perempuan (kaum Hawa). Sedangkan secara organisatoris atau kelembagaan dalam konsepsi tidak ada pimisahan yang tajam, bahwah di Muhammadiyah hanya untuk laki-laki saja dan begitu sebaliknya. Namun pada realitas praksisnya di Muhammadiyah terjadinya ketimpangang struktur makna, sistem dan kultural akibat adanya struktur yang terpisah. Sehingga ini menjadi sangat penting untuk dikaji kemabali, yang kemudia bagaimana untuk menemukan titik integrasi sebagai langka meredam kesenjangan struktur yang ada.

Pada level wacana kesetaraan gender di Muhammadiyah, terutama mengakomodir kaum perempuan telah lama menjadi wacana dan sekaligus menjadi perjuangan Aisyiyah sebagai basis sub-struktur dan kultur, namun kemudian pada wilayah praksis justru perjuangan itu selalu berbenturan dengan struktur yang ada di Muhammadiyah, terlebih lagi posisi organisasi Aisyiyah adalah organisasi otonom yang berada di bawah Muhammadiyah. Sehingga dapat dilihat bagaimana alur regulasi atau kebijakan terutama pada level struktur, nilai, ideologis dan sampai pada otoritas interpretasi teologis yang ikut mengkonstruksi dan terus direprodeuksi secara cultural-religius-politik terutama pada peran, fungsi dan status semua anggota Muhammadiyah, khususnya yang menyangkut hak-hak perempuan.

Di sisi lain, di Muhammadiyah selama ini belum adanya integrasi sosial dalam kehidupan sistem dan struktur, sehingga tidak dapat membuka kebuntuan alur dengan adanya pimisahan struktur di dalam institusi. Sehingga kemudian respon terhadap gagasan baru yang cukup relevan bagi organisasi sulit untuk merubah tatanan yang ada, karena sistem dan struktur yang telah mapan sulit diubah (Kuntowijoyo, 1993: 192) karena sistem, struktur da perilaku merupakan manifestasi dari kontruksi nilai sebagai ruh atas perilaku sosial. Kemudian selain yang di atas, yang menjadi problem kesenjangan gender selama ini adalah karena Muhammadiyah masih dikenal sebagai organisasi yang ortodoksi dalam artian faktor teologis masih menjadi problem bagi munculnya kesenjangan atas nama agama melalui interpretasi ke konteks sosial yang kompleks, khususnya yang 
menyangkut wilayah perempuan, sehingga perhatian terhadap perempuan belumlah begitu signifikan terutama pada level struktur organisasi. Dari berbagai diskursus gender terutama dalam ranah politik, ekonomi, kultur dan pendidikan masih menyisahkan berbagai promlematika yang masih menjadi sekedar wacana. Sebagai contoh yang masih terus menjadi wacana yaitu Ketua Umum Pimpinan Pusat Muhammadiyah belum perna ada perempuan, serta pengurus perempuan pada level struktur masih sangat sedikit sekali.

Kegelisahan para perempuan Aisyayiyah kemudian memunculkan refleksikan pasca Muktamar X Nasyiatul Aisyiyah yang berlangsung 8-11 Desember 2004. Organisasi otonom (ortom) Persyarikatan Muhammadiyah yang satu ini untuk pertama kalinya menggelar Muktamar yang lepas dari induknya di Asrama Haji Donohudan, Solo. ${ }^{1}$ Dengan mengakat tema "Menguatakan Peran Nasyiatul Aisyiyah dalam Pengambilan Kebijakan Publik”. Ortom ini bermaksud menyuarakan aspirasi perempuan di Persyarikatan Muhammadiyah. Secara eksplisit, untuk dilibatkan perempuan secara langsung dalam setiap pengambilan kebijakan berkenaan dengan permasalahan umat (sosial, politik, pendidikan, agama dan persoalan kemanusiaan). Tentunya tuntutan untuk ikut berpartisifasi dalam pengambilan kebijakan membutuhkan "ruang" sebagai posisi yang diperhitungkan.

Selama ini Muhammadiyah masih terlalu sedikit melibatkan peran perempuan dalam organisasi sosial keagamaan yang besar setelah Nahdlatul Ulama (NU). Sehingga organisasi yang didirikan oleh K.H.A. Dahlan ini, samapi sekarang banyak didominasi oleh "kaum Adam” laki-laki (Mu'arif, 2005:108) Padahal kader Muhammadiyah bukan hanya dari kalangan kaum Adam saja, akan tetapi kader-kader Muhammadiyah juga banyak dari kalangan "kaum Hawa" (perempuan). Hal ini tentu merefresentasikan bahwa peran perempuan sudah selayahnya diperhitungkan di Muhammadiyah, dan sekaligus merupakan satu bentuk perjuangan dalam setiap pengambilan keputusan di Muhammadiyah.

Menjadi catatan signifikan dari Nasyiatul Aisyiyah, bahwa peran perempuan harus diperhitungkan, ini terindikasi dengan adanya agenda ortom menunjukkan eksistensi baik di dalam Muhammadiyah ataupun di pentas

\footnotetext{
${ }^{1}$ Harian Kedaulatan Rakyat, 9 Desember 2004.
} 
nasional. Dari konstruksi sosial yang di bangun dalam masyarakat jawa ada terminology yang notabene ada satu keyakinan secara kultural bahwa permpuan telah mempunyai tempatnya sendiri yaitu keluarga dan suami mereka sebagai penjaga bagi perempuan (Koentjaraningrat, 1984:245), tentu stereotipe itu sebetulnya yang ingin dihindari oleh kaum perempuan di Muhammadiyah.

Suatu kenyataan bahwa masyarakat hidup dalam konteks sosial yang kompleks sehingga berbagai demensi kehidupan bersentuhan erat satu sama lain. Masyarakat yang secara totalitas merupakan bentuk interaksi yang sarat dengan sistem nilai (value system), kultur, agama dan berbagai ekspektasi sosial. Dari keberagaman sosial yang ada seringkali justru agama menjadi titik singgung paling sensitif, eksplosif dan eksploitasi dalam kehidupan masyarakat (Imam Baehaqi, 2002:v). Berbagai unsur sosial-keagamaan yang ada di Muhammadiyah turut mengkonstruksi satu bangunan sistem yang terpola menunjukkan bagaimana kehidupan sosial diatur dan di organisir secara sistemastis (David Berry, 2003:15).

Satu keniscayaan bahwa kehidupan berdampingan secara indikatif menunjukkan adanya kehidupan dua kutub jenis kelamin yang berbeda, namun lebih jauh kehidupan antar dua kutub jenis kelamin yang berbeda menjadi satu tema central yang selalu relevan untuk dikaji dan menyimpan berbagai problematikanya. Di zaman kontemporer banyak kita temukan berbagai kekerasan berbasis gender seperti domestic violence, penganiayaan terhadap istri, kekerasan fisik dan sampai kekerasan psikologis. Semua itu berangkat dari satu ideologi yang menjadi legitimasi penindasan satu pihak terhadap pihak lain (Ridwan, 2006:1), sebenarnya kekerasan terhadap perempuan adalah manifestasi dari pola dan pelembagaan suatu sistem sosiao-kultural yang terus di reproduksi secara alamiah oleh paradigm yang keliruh. Di lain pihak pranata dan lembaga sosial turut melegitimasi atas berbagai perilaku yang kemudian menjadi fakta sosial (Irwan Abdullah, 2006:4).

Berangkat dari kerangka sistem yang ada, maka status-status dan peranperan yang dimainkan oleh perempuan akan terikat pada sistem dan struktur nilai dan kultur yang ada di Muhammadiyah. Secara historis perbedaan gender (gender differences) antara jenis kelamin laki-laki dan perempuan melalui fase proses yang sangat panjang, yang tidak hanya melihat bagaimana jenis kelamin secara 
biologis, namun lebih jauh perbadaan gender secara sosio-kultural justru memperkuat perbedaan kearah diskriminatif, sehingga tidak hanya wilayah kodrati semata, namun terbentuknya konstruksi sebagai legitimasi bahwa perbedaan dianggap menjadi ketentuan Tuhan. ${ }^{2}$ Proses ketimpangan ini berawal dari berbagai hal, dari proses pembentukan, disosialisasikan, diperkuat dan dikonstruksi secara sosial dan kultural baik melaui ajaran agama maupun negara (Mansur Fakih, 2006:9).

Perbedaan gender sesungguhnya tidaklah menjadi masalah sepanjang tidak melahirkan ketidakadilan gender (gender inequalities) (Mansur Fakih, 2006). Namun yang menjadi masalah, ternyata perbedaan gender justru melahirkan berbagai ketidakadilan dan marginalisasi atau peminggiran terhadap yang lemah, baik bagi kaum laki-laki dan terutama bagi kaum perempuan. Untuk mengidentifikasi sejauh mana perbedaan gender melahirkan ketidakadilan dapat dilihat melalui bagaimana akses, kesempatan, partisifasi, kontrol serta manfaat bagi kaum perempuan dalam mendapatkan hak asasi manusia terutama, hak hidup, pendidikan, agama dan akses publik secara adilan. Berbagai bentuk manifestasi ketidakadilan gender yang lahir dari perbedaan gender (gender differences), yakni:

Pertama, adanya marginalisasi merupaka proses peminggiran yang mengakibatkan kemiskinan dalam berbagai dimensi kehidupan, rumah tangga, masyarakat dan negara. Dalam kehidupan domestik, perempuan tidak terlepas dari kekerasan dalam rumah tangga (domestic violences) yang dalam banyak hal dilegitimasi oleh keyakinan beragama (theologies) yang bias gender (Nur Said, 2005:xiii). Pada hal relasi suami istri adalah relasi kemitraan, bukan kekuasaan (Husein Muhammad, 2007: xxxiii). ${ }^{3}$ Dalam arti lain perempuan harus dipandang sama seperti laki-laki dalam mendapatkan hak-hak asasi manusia. Sementara dari

\footnotetext{
${ }^{2}$ Akar atau genealogi kontruksi disini yang terus direproduksi secara "massal" berawal dari kontruksi pemahaman agama yang secara tekstual, sehingga seringkali mengabaikan konteks sosio-kultural. Dimana agama telah menjadi bagian realitas yang kompleks yang pada gilirannya doktrin agama menjadi basis nilai dalam relasi laki-laki dan perempuan yang secara historis menjadi ideologi.

${ }^{3}$ Banyak orang beranggapan bahwa masalah penindasan terhadap perempuan adalah masalah yang tidak besar, padahal masalah yang dihadapi perempuan (ketidakadilan dan subordinasi) adalah masalah besar, karena perempuan adalah bagian dari manusia, sehingga ini menjadi masalah kemanusiaan.
} 
berbagai disiplin ilmu Islam tradisional yang mapan yaitu; ilmu fiqh (ilm al-fiqh), kalam (ilm al-kalam), tasawuf (ilm al-tashawwuf) dan falsafah (al-falsafah), ilmu fiqh yang paling mendominasi pemahaman umat muslim (Nurcholis Madjid,1995: 235) ${ }^{4}$ Sehingga perempuan seringkali hidup dalam tekanan teologis, namun ironisnya kekerasan domestik dianggap sebagai urusan "private" yang jauh dari ruang publik dan semata-mata dianggap urusan keluarga yang tidak boleh ada interpensi pihak lain, sehingga akan melanggengkan ketidak adilan.

Kedua, Subordinasi yang merupakan stigma bahwa perempuan tidak rasional (irrational) atau emosional sehingga perempuan tidak bisa tampil memimpin, sehingga terjadinya diskriminasi yang justru merugikan perempuan, perempuan hanya di dapur dan di kasur. Kalau kita mencoba melihat sejarah Indonesia memiliki bukti yang menunjukkan bahwa perempuan bahkan sangat mungkin menjadi panglima perang seperti Cut Nyak Dien, Megawati menjadi pemimpin nasional, kita juga melihat bahwa Margareth Thatcher, Cory Aquino, Sirimavo Bandaranaike adalah seorang ibu rumah tangga (Loekman Soetrisno, 2001: 16 ). Seyogyanya makna pemimpin tidak hanya dimaknai secara sempit seperti yang di konstruksi selama ini sebatas pada kekuasaan dalam hal politik semata. Namun di sisi lain, pemimpin merupakan bentuk eksistensi di mana perempuan mempunyai peran, kedudukan berkuasa, berwenang dan mempunyai posisi tawar (bergaining position) dalam menentukan keputusan dalam kehidupan masyarakat. Dalam masyarakat yang ada sekarang justru dominasi politik, kultural, demokrasi dan ekonomi turut melegitimasi (Julia Cleves Mosse, 2007:61) dan memperkuat tradisi subordinasi yang sangat patriarkal. Sehingga metamorfosa realitas sosial hanya berganti waktu dan tempat, di lain pihak sistem dan struktur serta tatanan nilai masih di dominasi kultur masa lalu yang dilanggengkan.

Ketiga, Stereotipe atau pelabelan negatif, bahwa perempuan secara kultural diperlakukan sebagai makhluk sekunder (secon dary creation) yang

\footnotetext{
${ }^{4}$ Agama tidak hanya didekati dan dipahami melalui pendekatan teologis-normatif semata, sesui dengan konteks yang ada, maka terjadinya pergeseran paradigma pemahaman terhadap "Agama" (dari "doktrim" ke arah entitas "sosiolagis"). Sehingga banyak ruang unruk melihatdan menginterpretasikan "Agama" secara aspektual, dimensional dan bahkan multi-dimensional approaches. Di sisi lain "tradisi" agama sulit dipisahkan dari faktor "human construction" yang dipengaruhi oleh perjalanan sejarah sosial-ekonomi-politik dan kultur.
} 
mempunyai tugas demestik serta memelihara lingkungan hidup lagi pasif (Sachiko Murata, 1997:7) ${ }^{5}$ sehingga itu bukanlah sifat alamiah perempuan melainkan sifat yang dikulturkan oleh sistem patriarkhi. Kemuadian dalam berbagai kondisi sifat dasar keperempuanan menjadi di nisbikan oleh berbagai kepentingan-kepentingan yang justru tanpa di sadari telah membentuk penjarapenjara kecil, dari wilayah domestik sampai publik. Secara kolektif justifikasi seringkali dilabelkan pada kelompok-kelompok tertentu, terutama pada perempuan yang berawal dari asumsi-asumsi yang mengarah kepada ketidakadilan yang akhirnya merugikan perempuan karena imejnya sangat rendah dan lemah di masyarakat.

Bahwa perempuan memiliki hak inferior pada definisi mentalnya, walaupun status mereka yang seringkali dianggap rendah dalam berbagai interpretasi agama dan peran meraka hanya di gambarkan sebagai perempuan penggoda dan pusat nafsu syetan. Sehingga muncul streotipe bahwa perempuan "panjang rambut, tetapi pendek pikirannya" (Qosim Amin, 2003:20) dan kesan seperti itu terjadi sampai sekarang yang merupakan representasi bahwa perempuan diciptakan hanyalah untuk melayani kaum laki-laki. Sehingga sistem relasi gender perempuan dan laki-laki cenderung dihindari untuk diubah dalam revivalisme Islam, khususnya bagi penganut Islam "fundamental" di Muhammadiyah-pun masih kuat pemahaman seperti itu. Dari banyak tokoh Muhammadiyah yang penulis sempat diskusi di Yogyakarta pada tahun 2007, bahwa terminologi "gender" masih sangat asing bagi warga Muhammadiyah. Karena perubahan akan mengganggu kepentingan laki-laki yang mendominasi ataupun kelompok sosial, sehingga kelompok dominasi akan selalu menjaga status quo sistem relasi gender dengan justifikasi teologis, struktur yang a-historis (Wardah Hafidz, 1992:39).

Konstruksi Gender yang menjadi pokok dalam kajian ini yang secara eksplisit melihat relasi gender di organisasi Muhammadiyah. Bertolak dari konstruksi sosial-budaya yang terjadi dalam masyarakat melalui legitimasi doktrin, dogma, ideologi dan struktur yang kemudian di sisi lain menampilkan

\footnotetext{
${ }^{5}$ Dikulturkan atau kulturisasi yang merupakan bentuk proses konstruksi norma-norma sosial dalam rangka melanggengkan dan sekaligus sebagai legitimasi sistem nilai dan mendominasi agar perempuan selalu terkungkung dalam sekat ruang dan waktu (tertindas).
} 
ketidakadilan gender, terutama persoalan peran, fungsi akses, kontrol dan manfaat. Pemahaman tentang gender sangat beragam, terutama dalam perspektif yang beragam, sehingga tidak heran ketika kita menemukan berbagai pemaknaan yang berbeda-beda terutama dalam kajian yang berbeda pula, seperti gender dalam Islam, gender di Barat dan sebagainya. Di sini ada beberapa pemahaman para tokoh tentang gender antara lain sebagai berikut:

Julia Cleves Mosse mengartikan bahwa gender berbeda dengan jenis kelamin biologis yang merupakan pemberian, namun jalan yang menjadikan kita maskulin atau feminin adalah gabungan blok-blok biologis dasar dan interpretasi biologis oleh kultur kita. Sehingga gender pada dasarnya adalah seperangkat peran yang, seperti halnya kostum dan topeng di teater. Perangkat perilaku mencakup sikap, bekerja domestik dan publik, peran dan tanggungjawab (Julia Cleves Mosse, 2007:2).

Gender merupakan interpretasi budaya terhadap jenis kelamin yang pada gilirannya melahirkan seperangkat konsep budaya (Sri Suhandjati, (ed), 2002:3). Sehingga kemudian menjadi sistem sosial dalam masyarakat dan menjadi kultur sebagai perangkat dalam kehidupan. Sedangkan Mansour Fakih memaknai gender merupakan suatu sifat yang melekat pada kaum laki-laki maupun perempuan yang dikonstruksi secara sosial maupun kultur (Mansur Fakih, 2006: 8). Misalnya, bahwa perempuan dikenal lemah lembut, cantik, emosional, dan keibuan. Sementara laki-laki dikenal kuat, rasional, jantan dan perkasa. Sedangkan Ivan Illich, memaknai gender merupakan perbedaan perilaku dalam berbagai kultur, yang berbeda tempat, waktu, tugas, bentuk dan persepsi yang di hubungkan dengan laki-laki dan perempuan dalam kebudayaan (Ivan Illich, 2002: 3).

Pemaknaan dan interpretasi terhadap istilah konstruksi, banyak ilmuan terutama sosiolog dan antropolog berbeda dalam memberikan pemaknaan, terutama pada konteks di mana kata ini digunakan, terutama dalam hal lebih pada konteks sosiologis dalam membicarakan persoalan gender. Sehingga harus ada batasan dalam membicarakan konstruksi. Ada beberapa definisi mengenai konstruksi, di antaranya sebagai berikut:

John M. Echols dan Hassan Shadily memaknai construct sebagai gagasan atau konsep, sedangkan consrtuction merupakan pembuatan (John M. Echols dan 
Hassan Shadily, 2000: 142) atau proses pembangunan dari gagasan dan konsep yang menjadi standar nilai proses pelembagaan. Konstruksi secara sosial dalam hal gender merupakan perbedaan perilaku (behavioral differences) antara laki-laki dan perempuan yang dibentuk dan diciptakan oleh manusia melalui proses sosial dan kultur yang sangat panjang (Mansur Fakih, 2006: 71-72), melalui dinamika dan dialektika sosial yang kompleks.

Nasaruddin Umar memahami konstruksi sosial (social construction) merupakan proses di mana peran sosial yang selama ini dianggap baku dan dipahami sebagai doktrin keagamaan, bukanlah kehendak tuhan dan juga bukan produk determinis biologis, melainkan sesungguhnya hasil produk pembentukan secara sosial (Nasaruddin Umar, 2001: xxi). Atribut jenis kelamin secara kultur menjadi faktor penting dalam melegitimasi peran gender seseorang. Sehingga ketika jenis kelamin kelihatan, maka konstruksi sosial budaya telah terjadi melalui persepsi laki-laki dan perempuan. Kemudian atribut ini juga senantiasa digunakan untuk menentukan hubungan relasi gender (Sri Suhandjati (ed), 2002: 5), seperti fungsi, peran dan status laki-laki dan perempuan dalam masyarakat.

Dalam hal ini akan melihat fungsi, peran dan status yang berbasis gender dalam hubungan perempuan dan laki-laki dalam struktur organisasi Muhammadiyah. Sehingga mampu melihat kebijakan yang berbasis pada struktur dan sekaligus hubungan laki-laki dan perempuan yang seringkali menjadi legitimasi dalam pemetakan peran, fungsi dan satus, terutama pada wialayah akses, partisifasi dan kesempatan anggota memasuki wilayah struktur organisasi. Terutama dengan adanya pemisahan struktur di Muhammadiyah dan Aisyiyah.

Subyek penelitian menjadi pusat perhatian atau sasaran peneliti (Suharsimi Arikunto, 2002: 122). Subyek juga merupakan tempat di mana data dapat diperoleh, dalam hal ini adalah orang-orang Muhammadiyah dan Aisyiyah yang menjadi informen dalam penelitian ini, baik yang ada dalam struktur institusi ataupun warga Muhammadiyah di luar struktur institusi.Adapun yang menjadi lokasi penelitian ini adalah Muhammadiyah Yogyakarta, Daerah Istimewa Yogyakarta.

Pendekatan yang digunakan dalam penelitian ini adalah pendekatan sosiologis-fenomenalogis, di mana pendekatan tentang interrelasi agama, politik, 
ekonomi dan masyarakat serta bentuk-bentuk interaksi yang terjadi di antara mereka (konstruksi-reproduksi sosial). Penelitian lapangan dengan metode kualitatif, sesuai dengan pokok kajian dalam penelitian ini yaitu Agama, Konstruksi dan Reproduksi di Gender Muhammadiyah. Pandangan pendekatan sosiologis-fenomenologis, relasi sosial yang menjadi fenomena masyarakat, dorongan dan lembaga sosial-keagamaan mempengaruhi dan juga dipengaruhi oleh kekuatan-kekuatan sosial organisasi dan strtifikasi sosial (Dadang Kahmad, 2000: 52).

Kekerasan terhadap perempuan tidak hanya secara fisik, namun belenggu perempuan atas nama teologis yang telah menjadi bagian akar kebudayaan,( Hedwig Meyer-Wilmes, 2003:91) terinstitusi (struktur). Sehingga kenyataan ini merepresentasikan identitas (keterwakilan), ketergantungan pada sistem patriarki. Sehingga kemudian di dunia saat ini, khususnya di Muhammadiyah perempuan memduduki kelas dasar dalam masyarakat, karena dominasi posisi dan kontrol ekonomi, politik, dan sumber daya lebih dikuasai oleh laki-laki (Barbara C. Aswad, 1978:473), yang memungkinkan ruang gerak bagi perempuan sangat sempit dan sangat sulit untuk menembus sekat-sekat, ruang dan waktu.

Demi ketajaman analisis-kritis, pertanyaan atas problematika di atas dapat disederhanakan secara spesifik menjadi sub-sub masalah sebagai berikut:

1. Bagaimana posisi perempuan dalam sistem dan struktur organisasi Muhammadiyah?

2. Bagaimana proses konstruksi dan reproduksi budaya, agama dan gender dalam organisasi Muhammadiyah?

3. Bagaimana resistensi perempuan di Muhammadiyah terhadap budaya patriarki?

\section{B. Relasi Gender, Agama dan Muhammadiyah}

Studi relasi gender, agama dan kekerasan yang terus direproduksi, secara spesifik di sini penulis memetakan beberapa problem yang telah lama menjadi wacana sebagai acuan perbandingan untuk membahas persoalan gender. Wacana gender terkait dengan relasi dengan agama, mengacu ke karya Khalil Abdul 
Karim yang berjudul asli, Mujtama' Yatsrib Alaqah ar-Rajul wa al-Mar'ah fi Ahd an-Nabiy wa al-Khulafa' ar-Rasyidin, (2007: x-xi), bahwa relasi agama dan gender sebenarnya telah lama berlangsung sejak zaman nabi Muhammad Swt, namun konsep agama yang dihadirkan justru sangat humanis dan tidak terkesan bahwa perempuan berada dalam himpitan teologis dan HAM seperti yang terjadi di indonesia (Nur Said, 2005), bahkan Islam adalah agama yang ramah dan okomodatif dan menjunjung nilai keadilan terhadap perempuan (Husein Muhammad, 2007).Namun menjadi problem adalah ketika interpretasi agama yang sempit menjadi legitimasi atau argumen kesetaraan gender atas nama perspektif al-Qu'an (Nasaruddin Umar, 2001), seolah-olah agama tidak ramah terhadap perempuan.

Dengan demikian sudah seharusnya pemahaman terhadap Islam tantangan keadilan gender perlu diluruskan kembali dalam bingkai yang arif (Sri Suhandjati Sukri (ed), 2002). Bila perlu ada semacam dekonstruksi gender sebagai kritik terhadap wacana perempuan dalam Islam (Nasr Hamid Abu Zayd, 2003)

Tidak mengherankan ketika kita temukan berbagai ketidakadilan gender secara psiko-sosio-kultur terutama bagi perempuan untuk mendapatkan hakhaknya sebagaimana mestinya. Melihat relasi sosial, struktur masyarakat dan gerakan Muhammadiyah, dimana ada tradisi yang telah lama mengakar dalam bangunan konstruksi sosial yang kemudian Islam (teologis:teks) telah mengalami interpretasi ke dalam konteks sosial Muhammadiyah dengan latar belakang keilmuan, sosial, politik, historis yang berbeda dengan satu otoritas yaitu institusi yang mempunyai hak untuk memberikan fatwa (sosial, kultural, ekonomi dan politik). Kemudian muncul berbagai problematika sosial baru yang justru merugikan pihak lain (perempuan) terakait persoalan akses dan kesempatan.

Persoalan relasi gender, agama dan organisasi Muhammadiyah sering digugat di Muhammadiyah terkait konsep keluarga sakinah dalam Aisyiyah sebuah diskursus gender di organisasi perempuan Muhammadiyah (Ismah Salman, 2005: 3), memberikan perhatian terutama pada unit terkecil sosial yaitu keluarga. Di mana keluarga sebagai penunjang suatu sistem sosial melalui unit ekonomi, tempat reproduksi, kesatuan biososial dan sekaligus pembentuk kesatuan ideologi, nilai, dan agama. 
Kemudian kajian tematis keputusan-keputusan mejelis tarjih Muhammadiyah tentang perempuan (Samsuri dan Iffah Nur Hayati, 2006: 244), ini menjadi penting untuk melihat bagaimana legitimasi agama menjadi nilai konstruksi terhadap posisi dan pemaknaan Muhammadiyah terhadap para perempuan, khususnya di lingkungan Muhammdiyah. Sikap, ideologi dan perilaku Muhammadiyah dapat dibandingkan juga dengan sejauh mana konsistensi "proyeks" pengembangan pemikiran keislaman Muhammadiyah sebuah purifikasi dan dinamisasi ajaran Islam yang rahmatan lil alamin (M. Azhar, 2000). Purifikasi dan dinamisasi Muhammadiyah seharusnya mengungkapkan bahwa aktualisasi perempuan sebagai sumber daya dalam masyarakat dan pembangunan dari permpuan hanya dapat terjadi dalam situasi, kondisi, lingkungan dan masyarakat yang kondusif, yang menginginkan hal itu tejadi. Dalam arti perempuan tidak dibelenggu oleh "tradisi patriarki" sehingga perempuan mempunyai ruang untuk bergerak, berjalan secara kemitraan dengan laki-laki.

Konsep “pemberdayaan perempuan dalam Nasyiatul Aisyiyah”. (Nurul Alfiyah, 2001), mengindikasikan adanya bentuk kemandirian secara sosio-kultural dan sekaligus bentuk resistensi Nasyiatul 'Aisyiyah sebagai lembaga otonomi di dalam Muhammadiyah yang beranggotakan perempuan dan berupaya untuk dapat memberdayakan potensi yang ada pada perempuan. Sehingga apa yang dikatakan bahwa kodrat perempuan hanya menjalankan tugas 3M; Macak, Manak dan Masak tidak lah benar, sehingga tidak adanya sikap kombinasi secara berbeda antara laki-laki dan perempuan, laki-laki sebagai figur publik, sedangkan perempuan sebagai figur domestik, hal ini dapat dicarikan solusi, kesadaran, perubahan paradigma dan pengembangan potensi agar perempuan dapat memposisikan sebagai mitra yang sejajar.

\section{Konstruksi Budaya Patriarkal dan Reproduksi Gender}

Muhammadiyah merupakan salah satu organisasi sosial-keagamaan yang terbesar di Indonesia, yang berpusat di Yogyakarta, Daerah Istimewa Yogyakarta. Organisasi ini didirikan pada 8 Dzulhijjah $1330 \mathrm{H}$ atau 18 Nopember $1912 \mathrm{M}$ di Yogyakarta oleh K.H.Ahmad Dahlan (Margono Poespo Suworno, 2005: 25). 
Persyerikatan Muhammadiyah dikenal sebagai gerakan pemurnian dan pembaharuan dengan semboyan: “Kembali kepada Al-Qur'an dan al-Sunnah". Maksud Muhammadiayah pemurnian dan pembaharuan, serta kembali kepada AlQur'an dan al-Sunnah adalah segala aktifitas harus berlandaskan pada agama termasuk relasi laki-laki dan perempuan. Agama dapat dimaknai sebagai suatu bentuk teologis yang menjadi realitas ketuhanan di satu sisi, namun kemudian di sisi lain ketika agama telah mengalami internalisasi (Peter L. Berger, 1991:22-23) ke dalam konteks sosiologis mengalami persentuhan dan sekaligus dipengaruhi oleh berbagai latar belakang sosial, seprti ekonomi, politik, kebudayaan, sejarah dan geografis, maka agama menjadi produk sosial-budaya. Sehingga internalisasi merupakan poses dialektika yang sangat dinamis, dalam moment yang cukup besar juga terdapat pada eksternalisasi dan obyektivikasi kehidupan sosial Muhammadiyah. Dari proses dialektika, fenomena sosial di bentuk (social construction) melalui dialog yang cukup lama sehingga terciptalah tatanan nilai, sosio-kultur, sistem sosial yang kemudian membentuk lembaga-lembaga sosial, peran-peran, identitas dan "ideologi” dalam ruang kehidupan Muhammadiyah, manifestasi dari totalitas kontruksi nilai itu yang menjadi pola dan perilaku secara kolektif yang telah mendapat legitimasi dan menjadi konsensus sosial-budaya.

Mengungkap bahwa wacana gender yang selama ini adalah persoalan diskriminasi, marjinalisasi dan kekerasan terhadap perempuan, khususnya dalam akses, kesempatan dan peran perempuan, baik dalam sektor publik ataupun domestik, rangkaian itu telah memiliki simbol yang sarat dengan makna diskriminatif. Namun dalam perdebatan ini menyoroti pola relasi yang timpang antara laki-laki dan perempuan, mengkritik ideologi kultur yang berperan mengkonstruksi struktur yang membingkai relasi interpersonal pada level makro (Irwan Abdullah, dkk, 2002: v-vi), tataran praksis sosial maka dalam konteks Muhammadiyah ideologi berbasis nilai agama menjadi doktrin yang perlu dikritisi, karena agama bukan Tuhan, melainkan produksi sosio-kultural yang 
mempunyai dimensi sakralitas yang menjadi substansi nilai moralitas baik secara transendensi ataupun hablum minannas. ${ }^{6}$

Kajian ini fokus pada "struktur" organisasi Muhammadiyah, dengan melihat relasi perempuan dan laki-laki dalam tatanan struktur institusi, sosiokultural, peran agama, konstruksi dan reproduksi gender. Perhatian pada ketidakadilan atau kesenjangan bangunan struktur dan sistem ada di Muhammadiyah yang disebabkan oleh problem gender menjadi wacana utama (Mansur Fakih, 2006: 71). Meminjam istilah hegomoni Gramsci yang merujuk pada pengertian tentang situasi sosial-politik, dalam terminologinya disebut 'momen' di mana praktek sosial masyarakat Muhammadiyah menyatu dalam keadaan seimbang. Di sisi lain dominasi menjadi konsep dari realitas yang menyebar melalui sekaligus mewarnai ruang kehidupan masyarakat dalam sebuah lembaga dimana momen itu adalah Muhammadiyah. Sehingga pengaruh dari basis nilai (doktrin) Muhammadiyah menjadi 'spirit' berbentuk moralitas, adat, kultur, religi, prinsip-prinsip politik dan relasi sosial, terutama intelektual (Nezar Patra dan Andi Arif, 2003:12). Di sisi lain dari konsep hegomoni dapat melihat atau menjabarkan dan menganalisa bagaimana masyarakat Muhammadiyah diorganisir atau diorganisasikan baik dalam structural ataupun relasi sosial lakilaki dan perempuan. Sehingga hegomoni menjadi satu bentuk penguasaan dengan cara yang sangat "elok", tanpa menyakiti secara fisik, namun lebih pada pengusaan pada gagasan, ide, emosianal dan struktur, sehingga totalitas manusi (perempuan) terperangkap dalam sangkar emas.

Dalam tatapan fungsionalisme struktural, oleh Robert Merton dan Talcott Parsons, secara sederhana Muhammadiyah dapat dimaknai sebagai suatu kondisi masyarakat sebagai sistem yang terdiri atas bagian yang saling berkaitan antar unsur sosial (Margaret M. Poloma, 2003: 23-29), seperti (agama, pendidikan, struktur politik sampai keluarga), yang pada gilirannya setiap elemen sosial laki-laki dan perempuan berperan dalam menjaga stabilitas atau social equlibrium, atau dalam kacamata kritisme kondisi ini adalah sebuah kestabilan yang dipaksakan untuk menjaga kepentingan (rezim).

\footnotetext{
${ }^{6}$ Relasi sosial atau bentuk kesalehan sosial, namun dimensi ini seringkali lepas dari ruh transendensi (hablum minallah) sehingga makna sosial kehilangan nilai-nialai keadilan, empati, kemitraan dan kejujuran khususnya dalam relasi antara laki-laki dan perempuan.
} 
Dalam pandangan Michel Foucult tentang relasi kuasa, (Michel Foucult, 1985) seks atau laki-laki dan perempuan merupakan suatu realitas sosial, politik, dan kebudayaan, Foucult melihat bahwa politik kekuasaan tidak bisa dilepaskan dari tubuh manusia karena akhirnya kepentingan politik adalah mendapatkan kepatuhan dari realitas sosio-kultural yaitu perempuan secara seksualitas. Melalui The Archeology of Knowledge, geneologi kekuasaan (Michel Foucult, 2002:viii) ${ }^{7}$ sebenarnya Foucult menujukkan bahwa nilai, makna dan norma moral ditentukan oleh pengetahuan-kekuasaan. Karena kebenaran selalu terhubung dan ada di dalam relasi kuasa dengan sistem-sistem kuasa yang menghasilkan dan mempertahankannya, dan ia terkait dengan kuasa sebuah "rezim" kebenaran.

Dalam dimensi yang berbeda bahwa agama terdiri dari berbagai simbol sosio-kultural yang memberikan suatu konsep tentang realitas dan interpretasi. Dalam hal ini basis agama di Muhammadiyah telah menjadi sistem budaya, yang kemudian terbentuklah realitas abstrak yang berupa ideologi, dogma atau doktrin untuk suatu realitas yang dengan realitas teori, dogma atau doktrin itu bukan merupakan kongruensi struktural (Bassam Tibi, 1999:13). Sehingga eksistensi agama telah menjadi persepsi nilai manusia mengenai realitas laki-laki dan perempuan baik-buruk, adil atau tidak adil, diskriminasi atau kesetaraan serta karakteristiknya.

Dalam masyarakat Islam di Indonesia, kerangka normatif telah menjadi satu bentuk keyakinan pada umumnya yang telah terlembaga menjadi basis kesadaran dan bangunan nilai yang kompleks (Hamim Ilyas, dkk, 2005:5), sehingga eksistensi agama menjadi sangat penting. Namun pada realitas sosial, perkembangan agama dalam masyarakat Muhammadiyah telah banyak mengalami pergulatan dengan berbagai pemikiran, interpretasi sosiologis, sosio-kultur dan politik. Sehingga dinamika yang terjadi pada wialaya praksis, pelembagaan sosial, kerangka teologis telah menjadi satu bentuk ideologi dan sekaligus dogma dalam

7 Michel Foucault, The Archeology of Knowladge, terj. M. Mochtar Zoerni, (Yogyakarta: Penerbit Qalam, 2002 ), hlm. viii, Lihat juga Haryatmoko, Etika Politik dan Kekuasaan (Jakarata: Kompas, 2003), hlm.216, lalu bandingkan juga dengan George Ritzer, The Postmodern Society Theory, terj. Muhammad Taufik, Teori Sosial Postmodern (Yogyakarta: Juxtapose kerjasama Kreasi Wacana, 2005), hlm. 109 
kehidupan sosial. Karena proses dinamika pada wilayah sosiologis telah membentuk alur pemikiran menjadi sebuah bentuk social constructed (Peter L. Berger dan Thomas Luckman, 1990).

Dari proses pelembagaan agama, yang kemudian kita mengenal adanya organisasi keagamaan Muhammadiyah yang merupakan fenomena kolektivitas manusia, sehingga agama menjadi sangat penting bagi kehidupan sebagai norma dan kontrol atas perilaku, yang sekaligus menjadi kesadaran kolektif. Namun organisasi keagamaan seperti Muhammadiyah pada umumnya dapat dijumpai di masyarakat di mana fungsi diferensiasi internal dan stratifikasi sosial dibentuk oleh nilai budaya. Di lain pihak idoelogi yang menjadi basis pranata dan lembaga sosial turut melegitimasi yang kemudian menjadi fakta sosial (Irwan Abdullah (ed), 2006:4).

Ketimpangan sosial yang berbasis ketidakaadilan gender di Muhammadiyah masih cukup kuat, sehingga kemudian kemunculan subordinasi, streotipe, beban ganda, dan berbagai stigma yang justru telah mengakar menjadi tradisi pada masyarakat Muhammadiyah, salah satu yang perlu menjadi pertanyaan mendasar adalah istilah "gender" di Muhammadiyah justru belum popular mengingat masih banyak dari kalangan mereka yang menolak istilah itu. Karena tidak dipungkiri bahwa semua institusi atau organisasi sosial-keagamaan berusaha untuk membentuk tingkahlaku manusia sesuai dengan pola yang ditentukan oleh organisasi, baik pola yang ditentukan lewat jalur doktrin agama (ideologi), ajaran etnik maupun filsafat politik (Elizabeth K. Nottingham, 2002:121).

Masyarakat perempuan menjadi entitas sosial yang sangat penting dalam menjalankan tugas sosial yang bersifat patner, kerjasama dengan baik. Sehingga tidak relevan ketika perempuan selalu ditempatkan pada posisi marginalisasi yang menunjukkan bahwa perempuan menjadi second sex, atau sering disebut sebagai "warga kelas dua" yang keberadaan (existence) tidak begitu diperhitungkan (Istibsyaroh, 2004: 63). Karena kalau kita lihat realitas sosial yang ada, justru peran perempuan sudah semestinya diperhitungkan terutama dalam pengambilan keputusan, kepemimpinan dan berbagai peran publik lainnya, di Muhammadiyah sendiri peran perempuan tidak perlu diragukan lagi baik di Ortom Aisyiyah 
maupun di dalam system dan struktur Muhammadiyah. Pengelaman empirik penulis bertahun-tahun bergaul dengan orang Muhammadiyah, justru perempuan sangat berjasa dalam pengembangan amal usaha Muhammadiyah seperti (sekolah, rumah sakit, panti asuhan, perguruan tinggi dan amal usaha lainnya).

Di sisi lain ketika berbicara peran dan posisi perempuan, terutama dalam hal kepemimpinan di suatu organisasi sosial keagamaam, dalam hal ini adalah Muhammadiyah. Tentu telah menjaadi keharusan untuk membidik realitas ini sebagai realitas sosial yang cukup kompleks, terutama bagaimana agama dan perilaku keagamaan dianggap sebagai gejala sosial, (Syamsuddin Abdullah, 1997:19) yang memperlihatkan berbagai struktur dari institusionalisasi sosial keagamaan, sehingga kemudian dapat kita lihat posisi bahkan peran manusia; lakilaki dan perempuan dalam pergulatan sosial di mana konstruksi sosial turut memainkan peran dalam membentuk kerangka sistem, struktur dan sistem nilai budaya dalam kehidupan masyarakat Muhammadiyah.

Ajaran agama sangat kuat terhadap sistem nilai yang ada dalam kebudayaan masyarakat Muhammadiyah, sehingga sistem nilai dari masyarakat tersebut terwujud sebagai simbol-simbol suci yang maknanya bersumber dari suatu ideologiatau ajaran agama yang menjadi kerangka acuan dalam perilaku sosial.(Roland Robertson, 1998:vii)

Pembangunan organisasional merujuk kepada kegiatan-kegiatan yang dimaksud untuk mencapai perubahan di dalam tubuh organisasi dalam konteks ini adalah organisasi Muhammadiyah, dengan sasaran meningkatkan efisiensi dan efektifitas kerja, termasuk hubungan timbal balik dalam konteks hubungan organisasi di antaranya kegiatan advokasisosial. Untuk menganalisis organisasi, banyak sekali caranya akan berguna bila kita memecahkan konsep tentang organisasi menjadi unsur-unsurnya, di mana di tiap unsur dapat kita kaji strukturstruktur dan proses tergendernya. Bicara tentang organisasi secara umum, Swiering dan Wierdsma (1992: 10-11) mengidentifikasi empat unsur yang ada di tiap organisasi, yang menentukan perilakunya. (Mandy Macdonald, 1999: 2-3):

a. Strategi, merupakan sasaran organisasi dan cara-cara yang ditempuhnya untuk mencapai tujuan. 
b. Struktur merupakan pengelolaan dan pembagian tugas-tugas, wewenang serta tanggung jawab, posisi-posisi relatif dan hubunganhubungan formal antar anggota.

c. Sistem menjadi syarat-syarat dan kesepakatan-kesepakatan yang terkait dengan tata cara (informasi, komunikasi dan pembuatan keputusan serta aliran sumber daya (uang, barang dan SDM).

d. Budaya merupakan perpaduan atau penjumlahan pendapat-pendapat perorangan, nilai-nilai yang dianut bersama, norma-norma yang diikuti oleh para anggota.

Secara organisatoris Muhammadiyah samapai saat ini dengan gagasan purifikasi Islam seharusnya baik pada level sosio-kutural maupun struktur organisasi harus lebih adil dan equal, namun gagasan itu sayangnya hanya dimiliki faksi dari salah satu golongan aliran yang ada di Muahammadiyah yaitu aliran yang berpandangan "liberal" yang lebih lunak dan apresiasi terhadap persoalan gender. Dalam hal ini dapat ditemukan bahwa perubahan-perubahan yang mempengaruhi kedudukan dan peran perempuan terkait erat dengan struktur ekonomi dan sosial suatu masyrakat.( Nawal El Saadawi, 2001:183-184)

Oleh sebab itu kita harus lebih adil dalam membangun hubungan sosial; tradisi, identitas dan kekuasaan yang selama ini telah terbangun dalam pengelaman kehidupan masyarakat yang beragam.(Fatma Muge Gocek and Shira Balaghi, 1994:1). Sehinggga dalam studi gender yang menjadi keinginan yang harus dimaknai bagaimana konstruksi identitas antara perempuan dan laki-laki, karena itu merupakan hal yang sangat krusial. Dalam tataran struktur yang ada selama ini secara hirarkis struktur yang ada justru menekan atau menindas kaum perempuan. Dari rentetan itu semua perubahan paradigama tentang perempuan menjadi keyword dan mencoba untuk membangun suatu struktur sebagai alternatif yang ideal yaitu; berbagi kuasa (sharing power); menjadikan pengalaman kaum perempuan sebagai basis untuk perubahan sosial ( Jeri Dawn Wine and Janice L. Ristock, 1991:41). 


\section{Kesimpulan}

Membincangkan gender di Muhammadiyah tidaklah lengkap tanpa meruntut akar genealogi agama sebagai basis nilai sosial, budaya dan politik dalam ruang kehidupan Muhammadiyah. Seperangkat nilai itu dikonstruksi melalui proses historis yang cukup panjang dan muncul apa yang disebut ideologi tentang relasi laki-laki dan perempuan, kondisi ini memperlihatkan manifestasi adanya budaya patriarki sebagai realitas sosio-kultural dengan paradigma yang khas Muhammadiyah. Hal ini menegaskan bahwa agama sebagai realitas sosiokultural adalah bahwa agama telah menjadi produk sosial, namun secara substansial nilai agama telah mewarnai ketimpangan gender dimana agama menjadi bagian legitimasi yang terus direproduksi dan diperkuat oleh interpretasi secara sosial.

Konsesnsus sosial yang telah terlembaga di Muhammadiyah inilah bagian dari ketimpangan gender yang banyak mendapat resistensi dari para perempuan di Muhammadiyah, khususnya dari Aisyiyah. Karena proses institusionalisasi seperangkat nilai itu justru melahirkan batasan secara sosio-kultural dan politik terhadap akses, kesempatan, partsisipasi dan bargaining position bagi perempuan, sehingga ruang-ruang itu diperkuat oleh sistem dan struktur baik kelembagaan Muhammadiyah maupun sistem dan struktur makna, nilai, simbol pada wilayah praksis sosial. Untuk membangun pola relasi yang equal dan kemitraan tentu harus ada perubahan paradigma, khususnya paradigm pemahaman agama yang lebih inklusif, toleran dan emansipatif baik pada wilayah kelembagaan Muhammadiyah maupun pada ranah sosial amal usaha Muhammadiyah.

\section{E. Daftar Pustaka}

Abdullah, Amin, 2004. Studi Agama Normativitas dan Historisitas. Yogyakarta: Pustaka Pelajar.

Abdullah, Irwan (ed), 2006. Sangkan Paran Gender. Yogyakarta: Pusat Studi Kependudukan UGM kerjasama Pustaka Pelajar.

Abdullah, Irwan, dkk, 2002. Islam dan Konstruksi Seksualitas. Yogyakarta: PSW IAIN Yogyakarta, The Fort Foundation dan Pustaka Pelajar.

Amin, Qosim, 2003. The New Women: A Documen in The Early Debate of Egyption Feminisme, terj. Syariful Alam, Sejarah Penindasan Perempuan, Menggugat "Islam Laki-laki” Menggurat "Perempuan baru”. Yogyakarta: IRCiSoD. 
Arikunto, Suharsimi, 2002. Prosedur Penelitian Suatu Pendekatan Praktek. Jakarta: PT Rineka Cipta.

Aswad, Barbara C, 1978. Women, Class, and Power: Examples from the Hatay, Turkey, in Lois Beck and Nikki Keddie (ed), To the Women of the Muslim Word. Harvard University Press.

Baehaqi, Imam (ed), 199. Agama dan Relasi Sosial. Yogyakarta: LKiS, 2002

Berger, Peter L. The Sacred Canopy, (terj), Hartono, Langit Suci Agama Sebagai Realitas Sosial. Jakarta: LP3ES.

Berger, Peter L. dan Thomas Luckman,1990. The Social Contruction of Reality, (terj), Hasan Basri, Tafsir Sosial Atas kenyataan. Jakarta: LP3ES.

Berry, David, 2003. The Principle of Sociology, (terj) Paulus Wirutomo, Pokokpokok Pikiran Dalam Sosiologi. Jakarta: PT Raja Grafindo Persada.

Beuken, Win dkk, 2003. Religion as a Source of Violence? (terj), Imam Baehaqie, Agama Sebagai Sumber Kekerasan. Yogyakarta: Pustaka Pelajar.

Echols, John M. dan Hassan Shadily, 2000. Kamus Inggris Indonesia. Jakarta: Gramedia.

Fakih, Mansur, 2006. Analisis Gender dan Tranformasi Sosial. Yogyakarta: Pustaka Pelajar.

Foucult, Michel,1985. The History of Sexuality vol I, New York: Random House, Inc,

Foucault, Michel, 2002. The Archeology of Knowladge, terj. M. Mochtar Zoerni, (Yogyakarta: Penerbit Qalam.

Furchan, Arief, 1992. Pengantar Metoda Penelitian Kualitatif. Surabaya: Usaha Nasional.

Hadi, Sutrisno, 1982. Metodologi Reserch. Jakarta: Yasbit Fakultas Psikologi UGM.

Hafidz, Wardah, Misogyny Dalam Fundamentalisme Islam, Jurnal Ulumul Qur'an, No. 1.Vol. III/th. 1992.

Hamim Ilyas, dkk, 2005. Perempuan Tertindas? Kajian Hadis-hadis "Misoginis". Yogyakarta: eLSAQ Press dengan PSW UIN Sunan Kalijaga Yogyakarta.

Harian Kedaulatan Rakyat, 9 Desember 2004

Haryatmoko, 2003. Etika Politik dan Kekuasaan, Jakarata: Kompas.

Katjasungkana, 2001. Nureyahbani, dkk. Potret Perempuan Tinjauan Politik, Ekonomi, Hukum di Zaman Orde Baru. Yogyakarta: PSW UMY bekerjasama Pustaka Pelajar.

Koentjaraningrat,1983. Penelitian Masyarakat. Jakarta: PT Gramedia.

Koentjaraningrat, 1984. Kebudayaan Jawa, Jakarta: Balai Pustaka.

Kahmad, Dadang, 2000. Metode Penelitian Agama. Bandung: Pustaka Setia.

Karim, Khalil Abdul, 2007. Mujtama' Yatsrib Alaqah ar-Rajul wa al-Mar'ah fi Ahd an-Nabiy wa al-Khulafa' ar-Rasyidin, (terj), Khairon Nahdiyyin, Relasi Gender Pada Masa Muhammad dan Khulafaurrasyidin. Yogyakarta: Pustaka Pelajar.

Illich, Ivan, 2002. Gender, (terj), Omi Intan Naomi, Matinya Gender. Yogyakarta: Pustaka Pelajar.

Moleong, Lexi J, 2000. Metodelogi Penelitian Kualitatif. Bandung: PT Remaja Rosdakarya.

Mosse, Julia Cleves, 2007. Half The Word, Harf A Chance, An Introduction to Gender and Development, (terj), Hartian Silawati, Gender dan 
Pembangunan. Yogyakarta: RIFKA ANNISA Women's Crisis Center dengan Pustaka Pelajar.

Mu'arif, 2005. Meruat Muhammadiyah, Kritik Seabad Pembaharuan Islam di Indonesia, Yogyakarta: Pilar Media.

Murata, Sachiko,1997. The Tao of Islam, Kitab Rujukan Tentang Relasi Genderdalam Kosmologi dan Teologi Islam. (terj), Rahmani Astuti dan M.S Nasrullah, Bandung : Mizan.

Muhammad, Husein, 2007. Islam Agama Ramah Perempuan. Yogyakarta: LkiS.

Madjid, Nurcholis, 1995. Islam, Doktrin dan Peradaban. Jakarta: Yayasan Wakap Paramadina.

Nasaruddin, Umar, 2001. Argumen Kesetaraan Jender; Perspektif Al-qur'an. Jakarta: Paramadina.

Nottingham, Elizabeth, 2002. Religion and Sociaty, (terj), Abdul Muis Naharong, Agama dan Masyarakat. Jakarta: Rajawali Perss.

Patra, Nezar dan Andi Arif, 2003. Antonio Gramsci, Nagara dan Hegomoni. Yogyakarta: Pustaka Pelajar.

Ridwan. Kekerasan Berbasis Gender, 2006. Purwokerto: Pusat Studi Gender STAIN Purwokerto kerjsama Fajar Pustaka Yogyakarta.

Ritzer, George, 2004. a multiple paradign science, (terj), Alimandan, Sosiologi Ilmu Berparadigma Ganda. Jakarta: Rajawali Pers.

Ritzer, George dan Douglas J. Goodman, 2004. Teori Sosiologi Modern, (terj), Alimandan. Jakarta: Rajawali Perss.

Ritzer, George, 2005. The Postmodern Society Theory, terj. Muhammad Taufik, Teori Sosial Postmodern, Yogyakarta: Juxtapose bekerjasama Kreasi Wacana.

Said, Nur, 2005. Perempuan Dalam Himpitan Teologi dan HAM. Yogyakarta: Pilar Media.

Salman, Ismah, 2005. Keluarga Sakinah dalam Aisyiyah: Diskursus Jender di Organisasi Perempuan Muhammadiyah. Jakarta: PSAP Muhammadiyah.

Samsuri dan Iffah Nur Hayati, Kajian Tematis Keputusan-keputusan Mejelis Tarjih Muhammadiyah Tentang Perempuan, dalam Jurnal Millah, Vol. V, No, 2, Februari 2006

Suworno, Margono Poespo, 2005. Gerakan Muhammadiyah, Yogyakarta: Penerbit Persatuan Baru.

Suhandjati, Sri (ed), 2002. Pemahaman Islam dan Tantangan Keadilan Jender. Yogyakarta: Gama Media kerjasama dengan Pusat Studi Jender IAIN Walisongo Semarang.

Tibi, Bassam, 1999. Islam and the Cultural Accommodation of Social Change, (terj), Misbah Zukfah Ellizabet dan Zainul Abas, Islam Kebudayaan dan Perubahan Sosial. Yogyakarta: Tiara Wacana. 